\title{
Isolation and Composition of an Alkali-soluble Glucan from the Cell Walls of Saccharomyces cerevisiae
}

\author{
BY G. H. FLEET* AND D. J. MANNERS $\dagger$ \\ Department of Brewing and Biological Sciences, Heriot-Watt University, \\ Edinburgh $E H$ I I $H X$
}

(Received 4 November 1975)

\section{SUMMAR Y}

An alkali-soluble glucan was obtained from the cell walls of Saccharomyces cerevisiae NCYCIIO9 and baker's yeast by extraction with cold, dilute sodium hydroxide under nitrogen. The glucan, which represented approximately $20 \%$ of the cell wall, precipitated as a gel when the alkaline extract was neutralized. The purified glucan was homogeneous and was shown to be free from contamination by other cell-wall polysaccharides by ultracentrifuging, gel filtration and electrophoresis. In addition to glucose, the glucan contained traces of mannose and nitrogen, but no hexosamine. Structural analyses revealed the presence of $80-85 \%$ $(\mathrm{I} \rightarrow 3)-\beta$-D linkages, $8-\mathrm{I} 2 \%(\mathrm{I} \rightarrow 6)-\beta$-D linkages and $3-4 \%$ branched residues linked through C-I, C-3 and C-6. The molecular weight of the glucan was estimated to be about 250000 . Electron-microscopic examination of the cell walls after alkali extraction showed that an amorphous surface layer had been removed revealing numerous bud scar structures.

\section{INTRODUCTION}

The biochemistry of the yeast cell wall has been comprehensively reviewed by Phaff (1963, 1971). The main cell-wall components of baker's yeast (Saccharomyces cerevisiae) are glucan and mannan type polysaccharides. Yeast mannan structure has been reviewed by Ballou (1974). Our previous studies have shown the presence of at least two types of glucan in baker's yeast cell walls: an alkali-insoluble, predominantly $(\mathrm{x} \rightarrow 3)-\beta$-D-linked glucan (Manners, Masson \& Patterson, 1973a); and an alkali-insoluble acetic acid-soluble, highly branched ( $\mathrm{I} \rightarrow 6)-\beta$-D-linked glucan (Manners et al., $1973 b$; Manners, Masson \& Patterson, 1974). However, reference has been made to the occurrence of a third glucan component in yeast cell walls, which, unlike the other two components, is extracted from the walls with alkali.

Roelofsen (1953) reported that approximately $25 \%$ of the total cell-wall glucan of baker's yeast was extracted with $2 \%$ sodium hydroxide at $100{ }^{\circ} \mathrm{C}$. Kessler \& Nickerson (1959) obtained an alkali-soluble glucan from the cell walls of $S$. cerevisiae using the milder extraction conditions of $\mathrm{I}$ M-potassium hydroxide at $30^{\circ} \mathrm{C}$ under nitrogen. This glucan was complexed with protein and mannan. However, extraction of cell walls from the related yeast $S$. carlsbergensis with cold, $3 \%$ sodium hydroxide under nitrogen yielded separate components of mannan and alkali-soluble glucan (Eddy \& Woodhead, 1968). In this case, the glucan represented approximately $20 \%$ of the initial cell-wall material.

These demonstrations that $S$. cerevisiae cell walls had an alkali-soluble glucan

* Present address: Department of Food Technology, University of New South Wales, New South Wales, 2033, Australia.

+ To whom communications should be addressed. 
component were not accompanied by any structural analysis. Since this glucan may well be a major cell-wall component, we initiated a study to confirm its presence and determine its chemical nature.

\section{METHODS}

Organism. Saccharomyces cerevisiae NCYCI 109 was maintained on $0.5 \%$ yeast extract + $5 \%$ glucose agar slants. Liquid cultures of the yeast were grown in $\mathrm{I} 1$ portions of the same medium (without the agar) in 21 conical flasks. Cultures were grown at $25{ }^{\circ} \mathrm{C}$ with shaking and cells in the late-exponential phase of growth were harvested by centrifuging. The cells were washed three times with $0.2 \mathrm{M}$-sodium phosphate buffer, $\mathrm{pH} 8.5$, and frozen until required for wall preparation. Commercial baker's yeast was obtained from the Distillers Co. Ltd, Edinburgh.

Preparation and extraction of cell walls. Cell walls of S. cerevisiae NCYCI IO9 and of baker's yeast were prepared by mechanical disruption in a Braun homogenizer as described previously (Fleet \& Phaff, 1973) except that sodium phosphate buffer, $\mathrm{pH} 8.5$, was used in place of Tris buffer. After washing approximately 20 times with buffer, and three times with distilled water, the cell walls were freeze-dried and stored in a desiccator. The walls were then extracted according to the protocol in Fig. I.

Analytical procedures. Total acid hydrolysis of glucan samples was done at $100{ }^{\circ} \mathrm{C}$ in $90 \%(\mathrm{v} / \mathrm{v})$ formic acid for $2 \mathrm{~h}$, followed by $\mathrm{M}_{-} \mathrm{H}_{2} \mathrm{SO}_{4}$ for $3 \mathrm{~h}$ as described by Peat et al. (I958). Partial acid hydrolysis was carried out at $100{ }^{\circ} \mathrm{C}$ with $90 \%$ formic acid for $\mathrm{I} h$, followed by $0.16 \mathrm{M}^{-\mathrm{H}_{2}} \mathrm{SO}_{4}$ for either $0.5 \mathrm{~h}$ or $\mathrm{I} \mathrm{h}$. Formic acid was effectively removed by adding water and evaporating the solution to dryness several times, before treatment with the $\mathrm{H}_{2} \mathrm{SO}_{4}$. Hydrolysates were neutralized with $\mathrm{BaCO}_{3}$ and, where necessary, deionized with mixed Amberlite IR-I 20 and Dowex I-X8 resins.

Reducing sugars were determined with an alkaline copper reagent (Spiro, 1966) and glucose was measured specifically with the glucose oxidase assay (Huggett \& Nixon, 1957). Total hexose was determined by the phenol-sulphuric method of Dubois et al. (1956). Nitrogen was determined by the micro-Kjeldahl method and hexosamine was estimated by the procedure of Elson \& Morgan (I933). For hexosamine analysis, the polysaccharides were hydrolysed with $4 \mathrm{M}-\mathrm{HCl}$ for $4 \mathrm{~h}$ under nitrogen at IIo ${ }^{\circ} \mathrm{C}$. Neutral sugars were removed from the hydrolysate using Amberlite IR-I20 resin, as described by Spiro (I966).

Descending paper chromatography was done with the following solvent systems: A, ethyl acetate-pyridine-water (I0:4:3, by vol.); B, n-propanol-ethyl acetate-water (I4:2:7); C, ethyl acetate-acetic acid-90\% formic acid-water (18:3:1:4). Sugar spots were detected using an alkaline $\mathrm{AgNO}_{3}$ reagent (Trevelyan, Procter \& Harrison, 1950). Column chromatography was carried out with either Sepharose 6B or Bio-Gel P-2 (200-400 mesh), as recommended by Pharmacia and Bio-Rad respectively.

The degree of polymerization (DP) of glucans was determined from the sorbitol content of an acid hydrolysate of the borohydride-reduced glucan by using sorbitol dehydrogenase (Manners, Masson \& Sturgeon, 1971).

For ultracentrifuging (Beckman, Model E), the glucans were dissolved in either $1.5 \%$ $\mathrm{NaOH}$ or $100 \%$ dimethyl sulphoxide (DMSO) and subjected to sedimentation velocity analysis using Schlieren optics.

Polyacrylamide gel electrophoresis of polysaccharides was done using $4.6 \%$ gels and $0.02 \mathrm{M}$-sodium tetraborate buffer, $\mathrm{pH} 9.5$. Electrophoresis was conducted in the cold $\left(4{ }^{\circ} \mathrm{C}\right)$ and at $300 \mathrm{~V}$ for $2 \mathrm{~h}$. Gels were sliced into $2 \mathrm{~mm}$ sections, incubated overnight in $\mathrm{I} \cdot 0 \mathrm{ml}$ water and then analysed for total carbohydrate. 


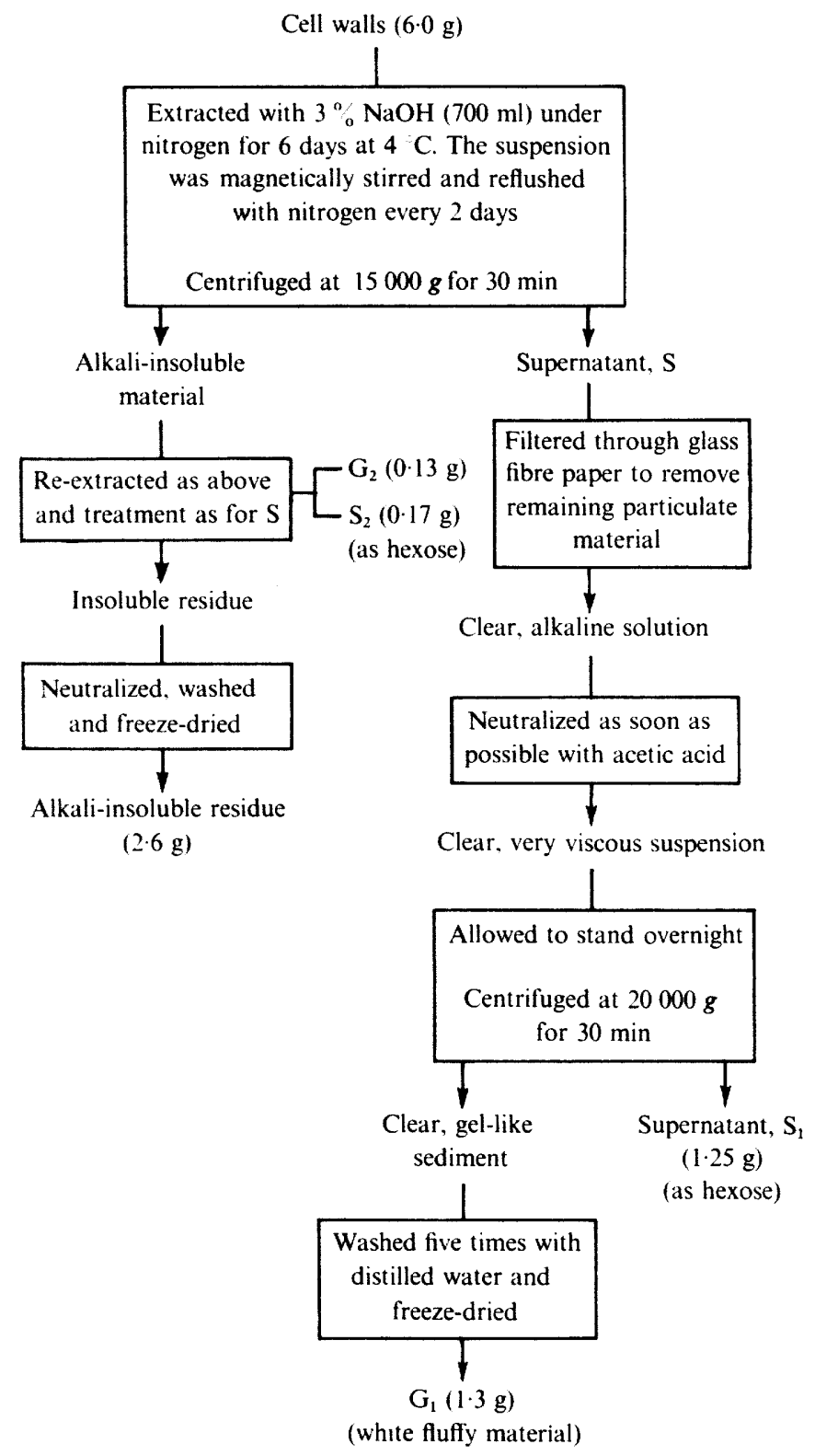

Fig. I. Procedure for extracting $S$. cerevisiae cell walls. Baker's yeast cell walls $(9 \cdot 0 \mathrm{~g})$ were similarly extracted (once only) giving $1 \cdot 2 \mathrm{~g}$ of $\mathrm{G}_{1}$ and $2.4 \mathrm{~g}$ of alkali insoluble residue. With this yeast, both $G_{1}$ and the insoluble residue failed to sediment firmly on centrifuging, resulting in lower yields.

Periodate oxidation analysis. The glucans were uniformly suspended in distilled water using a Potter homogenizer and concentrations were adjusted to $0.03 \mathrm{M}$-sodium metaperiodate and $2 \mathrm{mg}$ polysaccharide $/ \mathrm{ml}$. Oxidations were conducted in the dark at $4{ }^{\circ} \mathrm{C}$. Periodate reduction with time was monitored spectrophotometrically (Aspinall \& Ferrier, 1957). For Smith degradation (Goldstein et al., 1965), oxidation of the glucans (50 mg) was stopped after $96 \mathrm{~h}$ by adding ethylene glycol $(\mathrm{I} \cdot 0 \mathrm{ml})$ and the polysaccharide was 
recovered by centrifuging. After washing, the material was resuspended in water $(25 \mathrm{ml})$ and reduced with $\mathrm{KBH}_{4}(0 \cdot 15 \mathrm{~g})$. Reduction was carried out for $24 \mathrm{~h}$, and then the suspension

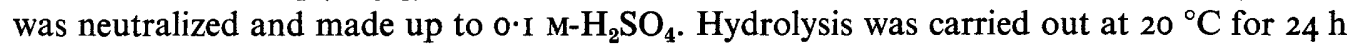
with shaking. Residual insoluble glucan was then isolated by centrifuging, washed and freeze-dried. The supernatant solution was neutralized, concentrated by rotary evaporation, and used for either column or paper chromatography. The latter was preceded by deionization as above.

Methylation analysis. Polysaccharides were methylated by the Hakomori method following the recommendations of Lindberg (1972). The methylsulphinyl sodium reagent was prepared according to the procedure of Sandford \& Conrad (1966), although clear, green solutions of the anion took about $2 \mathrm{~h}$ to form. Anion reagent $(5 \mathrm{ml})$ was added to a solution of the glucan $(20 \mathrm{mg})$ in dimethyl sulphoxide $(5 \mathrm{ml})$. After shaking overnight at $20{ }^{\circ} \mathrm{C}$ under nitrogen, an excess of methyl iodide $(5 \mathrm{ml})$ was added. The solution was allowed to stand for 5 to $6 \mathrm{~h}$, and then the methylated glucans were poured into water ( $100 \mathrm{ml}$ ), extracted with chloroform $(3 \times 100 \mathrm{ml})$, washed with water, and evaporated to dryness. At this stage, the polysaccharide was washed with ethanol, to avoid interference in subsequent gas-liquid chromatographic analysis. The procedure removed contaminating by-products of the methylation process leaving a clear, alcohol-insoluble polysaccharide. The methylated glucan was dried for subsequent hydrolysis or remethylation as required. Total acid hydrolysis was carried out as described previously. The methylated monosaccharides were converted into their alditol acetates (Lindberg, 1972) for analysis by g.l.c using a Pye series 104 gas chromatograph fitted with a glass column $($ I $50 \times 0.4 \mathrm{~cm})$ packed with $3 \%$ OV 225 on Gas Chrom Q (100-200 mesh). The methylated sugars were separated at $200{ }^{\circ} \mathrm{C}$ with nitrogen carrier gas at $20 \mathrm{ml} \mathrm{min}-1$. The identity of the methylated derivatives was confirmed by mass spectrometry (Bjorndal et al., 1970) using an AEI mass spectrometer coupled to a gas chromatograph.

Electron microscopy. Cell-wall preparations were allowed to dry on to carbon-coated formvar grids which were then shadowed at an angle of $12^{\circ}$ with platinum and examined in an AEI EM802 electron microscope.

Materials. Laminarin (Fleming, Hirst \& Manners, 1966), luteose (Nakamura \& Tanake, I963), baker's yeast ( $\mathrm{I} \rightarrow 6$ )- $\beta$-D-glucan (Manners $e t$ al., I973 $b$ ), and pachyman (Hoffmann, Simson \& Timell, I97I) were obtained from the departmental collection. Sclerotan was a gift from Dr J. S. D. Bacon (Jones, Gordon \& Bacon, 1974). Pustulan was purchased from Calbiochem, and dextrans T-I I0, T-250, and T-500 were obtained from Pharmacia.

\section{RESULTS}

\section{Wall extraction}

The alkali treatment dissolved $57 \%$ of the cell-wall material from S. cerevisiae I 109 (see Fig. I). The yields obtained for the various fractions accounted for over $90 \%$ of the initial wall material. The remaining $10 \%$ was accounted for by losses in washing and by substantial amounts of protein present in the $S_{1}$ and $S_{2}$ fractions. After heating (100 ${ }^{\circ} \mathrm{C}$ for $5 \mathrm{~min}$ ), fractions $S_{1}$ and $S_{2}$ reacted with Fehling's solution to produce dense flocculent precipitates, suggesting they had a high mannan content (Phaff, 1963). Precipitation with this reagent did not occur unless the fractions had been preheated. Fractions $S_{1}$ and $S_{2}$ were not studied any further. Fraction $\mathrm{G}_{1}$ accounted for $22 \%$ of the cell wall and is the subject of this investigation. Additional alkali treatment gave only minor amounts of $G_{2}$ which was not further examined. Baker's yeast $G_{1}$ was also prepared according to Fig. $I$. 
Table I. Chemical composition of cell-wall $G_{1}$ preparations

\begin{tabular}{lcc} 
Component & \multicolumn{2}{c}{ Composition $(\%)$} \\
Carbohydrate & I I09 & $\begin{array}{c}\text { Baker's } \\
\text { yeast }\end{array}$ \\
Nitrogen & 99.0 & 98.0 \\
Hexosamine & 0.13 & 0.26 \\
Glucose & 0.0 & 0.0 \\
Mannose & 98.5 & 97.0 \\
& 1.5 & 3.0
\end{tabular}

Solubility of $G_{1}$

The $G_{1}$ fractions from both yeasts were insoluble in water but readily soluble in $\mathrm{M}$-sodium hydroxide and $100 \%$ dimethyl sulphoxide (DMSO). Baker's yeast $\mathrm{G}_{1}$ took longer to dissolve than the $S$. cerevisiae I 109 preparation, requiring I to 2 days at $37^{\circ} \mathrm{C}$ in DMSO for complete dissolution. Neutralization of sodium hydroxide solutions of $G_{1}$ fractions with either acetic acid, glycine or hydrochloric acid produced gels at $\mathrm{pH}$ values below $10 \cdot 0$. However, if boric acid was used for neutralization, gelation did not occur until below $\mathrm{pH} 9 \cdot 0$, provided that the concentration of $\mathrm{G}_{1}$ was not greater than $5 \mathrm{mg} \mathrm{ml}^{-1}$.

\section{Chemical analyses}

Paper chromatographic analyses (solvent $A$ ) of total acid hydrolysates of $G_{1}$ from both yeasts revealed that they contained glucose plus minor amounts of mannose. Quantitative comparisons of specific glucose content and reducing-sugar equivalents of the hydrolysates showed $98.5 \%$ glucose and I. $5 \%$ mannose for the $S$. cerevisiae I 109 preparation, and $88.4 \%$ glucose and $I_{1} \cdot 6 \%$ mannose for baker's yeast $G_{1}$. Since the mannose in the latter hydrolysate could have been due to contamination from mannan present in the $S_{1}$ fraction, the $G_{1}$ preparations were washed with distilled water a further five times. The preparations were homogenized at each wash to ensure uniform suspension. The glucose and mannose contents of the washed fractions were then redetermined. There was no reduction in the mannose content of $\mathrm{G}_{1}$ from $S$. cerevisiae I I09, but the mannose content of the baker's yeast preparation dropped to $3 \%$, suggesting there had been some initial contamination with mannan. This was consistent with the difficulties encountered in isolating and washing this fraction (Fig. I). The final low mannose content of the washed $G_{1}$ fractions was not reduced by further washing and so was not considered to arise from $S_{1}$ contamination. The further washed $G_{1}$ fractions were used in all subsequent studies.

Table $I$ shows the results of the chemical analysis of the $G_{1}$ fractions. Both preparations contained a small amount of nitrogen, but no hexosamine.

\section{Partial acid hydrolysis}

Paper chromatographic analyses (solvents A and B) of partial acid hydrolysates from $\mathrm{G}_{1}$ fractions (20 $\mathrm{mg}$ ) of either yeast showed the following components: glucose, laminaribiose, laminaritriose, gentiobiose, laminaritetrose, laminaripentose, gentiotriose, laminarihexose, gentiotetrose, plus higher unidentified oligosaccharides. The laminarisaccharides showed much higher spot intensities than the gentiosaccharides. Partial acid hydrolysates of laminarin and luteose were run simultaneously, as controls, together with the appropriate standards. The results suggested that fraction $\mathbf{G}_{1}$ was predominantly a $(\mathrm{I} \rightarrow 3)-\beta$-Dlinked glucan containing a minor proportion of $(I \rightarrow 6)-\beta$-D linkages. 


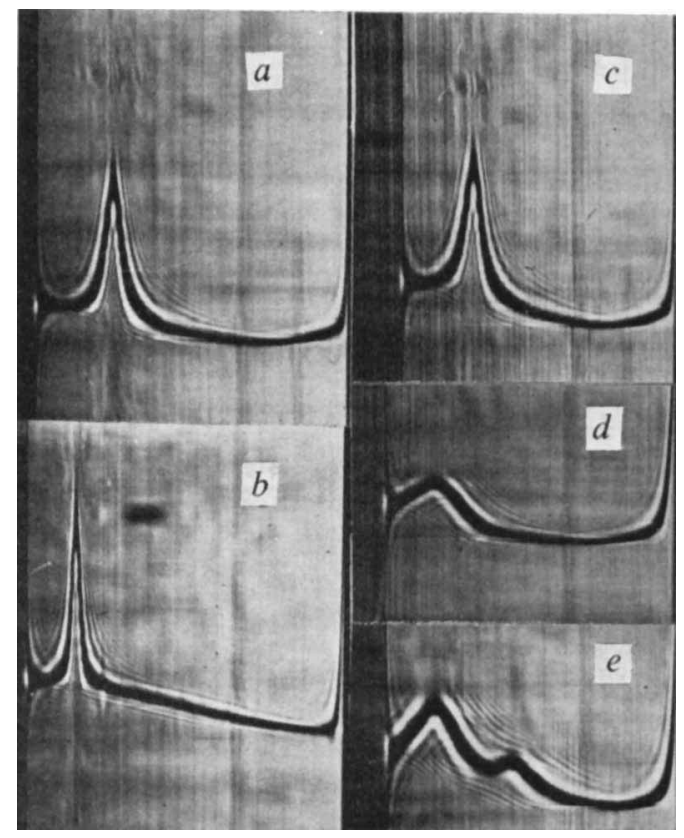

Fig. 2. Sedimentation patterns from ultracentrifuging of glucan samples. (a) $S$. cerevisiae $1109 \mathrm{G}_{1}$ in

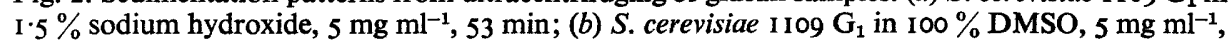
$\mathrm{I} 69 \mathrm{~min}$; (c) Baker's yeast $\mathrm{G}_{1}$ in $\mathrm{I} \cdot 5 \%$ sodium hydroxide, $5 \mathrm{mg} \mathrm{ml}^{-1}$, $49 \mathrm{~min}$; (d) Yeast (I $\left.\rightarrow 6\right)-\beta$ D-glucan in $\mathrm{I} \cdot 5 \%$ sodium hydroxide, $3 \mathrm{mg} \mathrm{ml}^{-1}, 76 \mathrm{~min} ;(e)$ Baker's yeast $\mathrm{G}_{1}, 3 \mathrm{mg} \mathrm{ml}^{-1}$ and yeast $(\mathrm{I} \rightarrow 6)$ - $\beta$-D-glucan, $3 \mathrm{mg} \mathrm{ml}^{-1}$, in $\mathrm{I} \cdot 5 \%$ sodium hydroxide, $72 \mathrm{~min}$.

\section{Homogeneity studies}

The small proportion of $(I \rightarrow 6)-\beta$-D linkages present in fraction $\mathrm{G}_{1}$ could arise from contamination with the $(\mathrm{I} \rightarrow 6)-\beta$-D-glucan described by Manners et al. (1973b), so the following experiments were conducted to investigate the possibility.

Ultracentrifuging of sodium hydroxide or dimethyl sulphoxide solutions of $G_{1}$ showed only one symmetrical boundary (Fig. 2). Figure 2 also shows the sedimentation patterns of baker's yeast $(\mathrm{I} \rightarrow 6)-\beta$-D-glucan and a mixture of this glucan and $\mathrm{G}_{1}$. At concentrations of $3 \mathrm{mg} \mathrm{ml}^{-1}$ in $\mathrm{I} \cdot 5 \%$ sodium hydroxide, $S$. cerevisiae $\mathrm{I}_{\mathrm{I} 09} \mathrm{G}_{1}$, baker's yeast $\mathrm{G}_{1}$, and yeast $(\mathrm{I} \rightarrow 6)-\beta$-D-glucan exhibited sedimentation coefficient values $(s)$ of $9.3,13.5$ and 3.9 respectively. At $5 \mathrm{mg} \mathrm{ml}^{-1}$ (in $\mathrm{I} \cdot 5 \%$ sodium hydroxide) the $S$. cerevisiae 1 I 09 preparation gave an $s$ value of 8.35 and baker's yeast $\mathrm{G}_{1}$ gave a value of 8.45 , indicating the effect of solute concentration on sedimentation behaviour. A $5 \mathrm{mg} \mathrm{m}^{-1}$ solution of $S$. cerevisiae I 109 $\mathrm{G}_{1}$ in $100 \%$ DMSO showed a much lower $s$ value of $\mathrm{I} \cdot 7$.

As mentioned previously, $\mathrm{G}_{1}$ preparations were maintained in solution at $\mathrm{pH} 9.5$ if alkaline solutions of the polysaccharide were neutralized with boric acid. Such solutions were chromatographed on Sepharose 6B. Although preparations of $G_{1}$ were excluded from this column, no polysaccharide was detected in those fractions where the yeast $(\mathrm{I} \rightarrow 6)-\beta$-D-glucan eluted (Fig. 3). However, on the basis of molecular size (see later), preparations of $\mathrm{G}_{1}$ should have been included in this column, not excluded. Solutions of pachyman, sclerotan and barley $\beta$-glucan were similarly excluded. The reason for this unusual behaviour is not understood, but it is possibly associated with the conformational state of the molecule. A more 


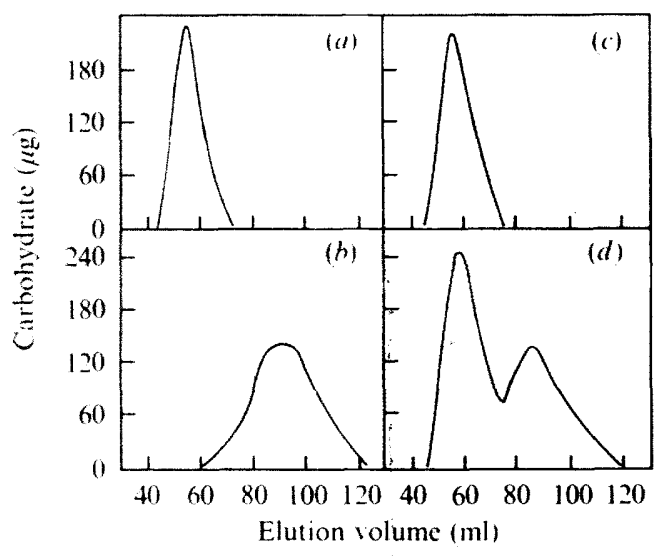

Fig. 3

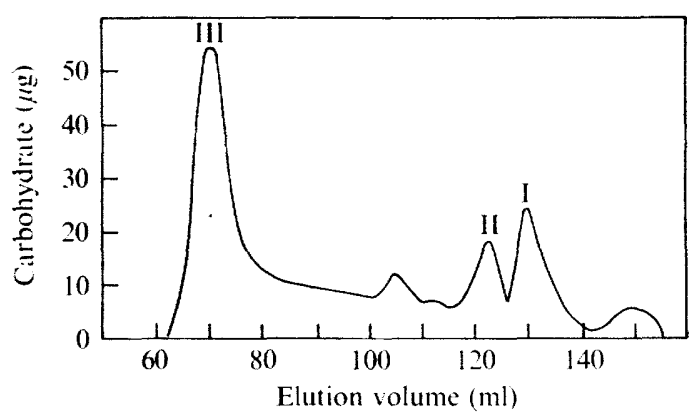

Fig. 4

Fig. 3. Sepharose $6 \mathrm{~B}$ chromatography of the cell-wall glucan fractions: (a) Baker's yeast $\mathrm{G}_{1}$; (b) Baker's yeast ( $\mathrm{I} \rightarrow 6)-\beta$-D-glucan; (c) $S$. cerevisiae $1109 \mathrm{G}_{1} ;(d) S$. cerevisiae $1 \mathrm{I} 109 \mathrm{G}_{1}$ and Baker's yeast $(\mathrm{I} \rightarrow 6)-\hat{\beta}$-D-glucan. Approximately $5 \mathrm{mg}$ of polysaccharide in $\mathrm{I} \cdot 0 \mathrm{ml}$ solvent was loaded on to the column $\left(85 \times 1.5 \mathrm{~cm} ; V_{\mathrm{t}} 150 \mathrm{ml} ; V_{\mathrm{o}} 56 \mathrm{ml}\right)$ which was equilibrated and eluted with $0.05 \mathrm{M}$-sodium tetraborate buffer, $\mathrm{pH} 9.5$. Flow rate was $5.0 \mathrm{ml} \mathrm{h}^{-1}$ and fractions of $3.0 \mathrm{ml}$ were collected.

Fig. 4. Bio-Gel P-2 chromatography of the soluble products from Smith degradation of the cell-wall $\mathrm{G}_{1}$ preparation from $S$. cerevisiae $\mathrm{I} 109$. The column (I $12 \times \mathrm{I} \cdot 5 \mathrm{~cm} ; V_{t} 200 \mathrm{ml} ; V_{0} 69.0 \mathrm{ml}$ ) was equilibrated and eluted with $0.05 \mathrm{M}-\mathrm{NaCl}$. Flow rate was $6.0 \mathrm{ml} \mathrm{h}^{-1}$ and fractions of $3.0 \mathrm{ml}$ were collected.

detailed study of the behaviour of these polysaccharides on gel chromatography has been published (Fleet \& Manners, 1975).

Preparations of $G_{1}$ (boric acid-neutralized solutions) did not penetrate the polyacrylamide gels on electrophoresis. However, under the same conditions, the yeast $(\mathrm{I} \rightarrow 6)-\beta$-D-glucan exhibited substantial movement $(2 \cdot 7 \mathrm{~cm}$ after I $\mathrm{h})$ towards the anode. No polysaccharide was found in this area of the gel on electrophoresis of $G_{1}$ preparations. The smaller $(I \rightarrow 3)-$ $\beta$-D-glucan, laminarin, migrated $5.4 \mathrm{~cm}$ after $\mathrm{I} \mathrm{h}$ and the dextrans $\mathrm{T}$-I IO and $\mathrm{T}-500$ migrated $0.9 \mathrm{~cm}$ and $0.3 \mathrm{~cm}$ respectively after $2 \mathrm{~h}$. The $(\mathrm{I} \rightarrow 6)-\beta$-D-linked glucans, pustulan and luteose (small molecular-weight molecules) did not enter the gels under the conditions used. In addition to molecular size, other factors influence the electrophoretic mobility of polysaccharides in polyacrylamide gels.

The above experiments show that the $(I \rightarrow 6)-\beta-D$ linkages present in the $G_{1}$ preparations are not due to contamination by the other cell wall $(I \rightarrow 6)-\beta$-D-glucan, and that fraction $G_{1}$ is probably a homogeneous polysaccharide.

\section{Molecular size}

Using the sorbitol dehydrogenase method, the $G_{1}$ preparation from baker's yeast exhibited a DP value of 1810 and the $S$. cerevisiae I 109 preparation gave a value of 1330 . Both values are considered to be accurate to within $\pm 10 \%$. Under the same conditions, the standard dextrans, dextran T-I I0, T-250 and T-500 gave DP values of 407, 877 and 1403 respectively, which correspond well with the $M_{n}$ values of 62000 , I41 000 and I 85000 published by the manufacturers.

\section{Methylation analysis}

Samples of fraction $G_{1}$ were fully methylated after three treatments using the Hakomori procedure. After only one methylation and subsequent hydrolysis and g.l.c. analysis, there 
Table 2. G.l.c.-methylation analysis of cell-wall $G_{1}$ preparations before and after Smith degradation

\begin{tabular}{|c|c|c|c|c|c|c|}
\hline \multirow[b]{3}{*}{$\begin{array}{l}O \text {-Methyl-D-glucitol } \\
\text { acetate derivative }\end{array}$} & \multirow[b]{3}{*}{$\begin{array}{l}\text { Retention } \\
\text { time }\end{array}$} & \multirow[b]{3}{*}{$\begin{array}{l}\text { Type of } \\
\text { linkage }\end{array}$} & \multicolumn{4}{|c|}{ Composition (mol \%) } \\
\hline & & & \multicolumn{2}{|c|}{ S. cerevisiae I I09 } & \multicolumn{2}{|c|}{ Baker's yeast } \\
\hline & & & $a$ & $\vec{b}$ & $a$ & $b$ \\
\hline $2,3,4,6$-Tetra- & $I \cdot 00$ & End-groups & 3.7 & $2 \cdot 2$ & $4 \cdot 7$ & $2 \cdot 5$ \\
\hline $2,4,6$-Tri- & $\mathrm{I} \cdot 67$ & $(\mathrm{I} \rightarrow 3)-$ & $84 \cdot 7$ & $94 \cdot 4$ & $79 \cdot 3$ & $95 \cdot 0$ \\
\hline $2,3,4$-Tri- & $2 \cdot 00$ & $(\mathrm{I} \rightarrow 6)-$ & $8 \cdot 3$ & 0.0 & $12 \cdot 0$ & 0.0 \\
\hline 2,4-Di- & 3.44 & $\begin{array}{l}\text { Branch point at } \\
\text { C-I, C-3 and C-6 }\end{array}$ & $3 \cdot 3$ & $3 \cdot 4$ & $4 \cdot I$ & $2 \cdot 5$ \\
\hline
\end{tabular}

$a$, Undegraded preparations; $b$, Smith-degraded preparations.

was no evidence of any unmethylated or monomethylated glucitol derivatives, which are indicators of incomplete methylation. However, three methylations were required to eliminate a minor peak of 2,6-di- $O$-methyl-D-glucose (considered as an artefact of undermethylation) and to obtain ratios of tetra- $O$-methyl and di- $O$-methyl derivatives that were consistent with a fully methylated polysaccharide. The data in Table 2 show that fraction $G_{1}$ contains mainly ( $I \rightarrow 3$ )-linked residues, with occasional branching at C-6, and a small but significant percentage of $(\mathrm{I} \rightarrow 6)$-linked residues. The baker's yeast preparation showed a slightly higher incidence of the latter type of linkage. The absence of derivatives of 2,3,6-tri- $O$-methyl-D-glucose from the hydrolysis products of the methylated glucans is evidence that the glucans are not contaminated with alkali-soluble glycogen (cf. GunjaSmith \& Smith, 1974). The methylated derivatives were identified by comparison with reference substances obtained from methylated polysaccharides of known structure (laminarin, Fleming et al., 1966; pustulan, Hellerqvist, Lindberg \& Samuelsson, 1968; sclerotan, Jones et al., 1974) and confirmation by mass spectrometry.

\section{Periodate oxidation analysis}

Both $G_{1}$ preparations reduced only small amounts of periodate, which is consistent with a predominantly $(\mathrm{I} \rightarrow 3)$-linked glucan containing a small percentage of $(\mathrm{I} \rightarrow 6)$-linked residues. Periodate reduction (which was constant after $20 \mathrm{~h}$ ) was 0.23 molecular proportions for the $S$. cerevisiae I 109 preparation, and slightly higher at 0.32 molecular proportions, as expected from the methylation studies, for the baker's yeast preparation. The contributions of the $(\mathrm{I} \rightarrow 6)$-linked residues to the periodate reduction results (cf. Table 2 ) are calculated to be 0.16 and 0.24 molecular proportions respectively.

On Smith degradation, $\mathrm{G}_{1}(50 \mathrm{mg})$ from $S$. cerevisiae I 109 yielded $27.4 \mathrm{mg}$ of an insoluble, resistant fraction, suggesting the presence of long sequences of $(\mathrm{I} \rightarrow 3)$-linked residues in the parent molecule. Since approximately $45 \%$ of the original molecule dissolved, some of the periodate-sensitive $(I \rightarrow 6)$ linkages must have been interspersed among sequences of $(I \rightarrow 3)$ linkages. On concentration, the dissolved material gave rise to additional insoluble polysaccharide $(7 \mathrm{mg}$ ). Paper chromatographic analysis (solvent $\mathrm{C}$ ) of the soluble products showed mostly glycerol $\left(R_{\mathrm{glc}} 3.5\right)$ and glucosyl-glycerol $\left(R_{\mathrm{glo}} \mathrm{I} \cdot 0\right)$, with traces of glycollic aldehyde $\left(R_{\mathrm{glc}} 2 \cdot 43\right)$ and slower-moving unresolved material. Column chromatography on Bio-Gel P-2 (Fig. 4) gave an excluded peak of carbohydrate (III) and several minor included peaks. Peak I was identified by paper chromatography as a mixture of glucosyl-glycerol and glycollic aldehyde. There was not sufficient material to identify the other peaks, but on the 
basis of elution volume, peak II is probably laminaribiosyl-glycerol. The baker's yeast $\mathrm{G}_{\mathbf{1}}$ preparation $\left(47^{\circ} 0 \mathrm{mg}\right)$ was also fragmented on Smith degradation and yielded $25^{\circ} \mathrm{mg}$ of resistant glucan.

The insoluble polysaccharide obtained after Smith degradation was subjected to methylation analysis (Table 2). As expected, this material was entirely $(\mathrm{I} \rightarrow 3)$-linked and contained no $(\mathrm{I} \rightarrow 6)$-linked residues. However, a small percentage of the residues were still tri-substituted at C-I, C-3 and C-6 as in the undegraded preparations. This implies the presence of structural unit (A) in the original molecule as opposed to the unit (B): the latter would have given rise to a more linear molecule on Smith degradation.

(A)

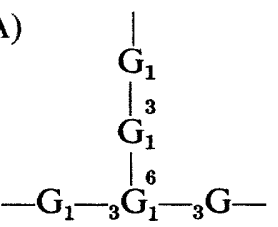

(B)

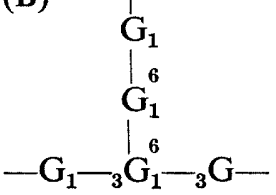

Buffer extraction of cell walls

Cell-wall mannan is routinely extracted by autoclaving yeast cells with sodium citrate buffer, $\mathrm{pH} 7 \cdot 0$ (Phaff, 197I). Extraction of isolated cell walls of S. cerevisiae I I09 according to this procedure gave rise to two distinct insoluble layers on centrifuging. The supernatant solution gave a precipitate with Fehling's solution and was presumed to contain mannan. The first of the insoluble layers $\left(B_{1}\right)$ was loosely packed and was readily separated from the more firmly sedimented layer $\left(B_{2}\right)$. The latter retained the original cell-wall shape and was not studied further. $B_{1}$ was washed five times with distilled water, then briefly examined. It was soluble in $\mathrm{M}$-sodium hydroxide and on acid hydrolysis gave mostly glucose. Incubation

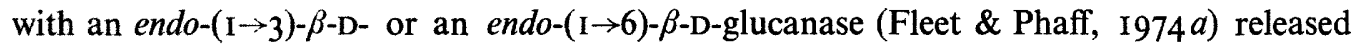
substantial quantities of reducing sugars indicating the presence of $(I \rightarrow 3)-\beta-D-$ and $(I \rightarrow 6)-$ $\beta$-D-glucosidic linkages. Fraction $\mathbf{B}_{1}$ was therefore considered to be very similar to the $\mathrm{G}_{\mathbf{1}}$ preparation described in this study.

\section{Electron microscopy}

The external surface of $S$. cerevisiae cell walls was very smooth (Fig. 5), and bud scars were not generally apparent. After the alkali extraction (Fig. I), the cell walls exhibited a somewhat deformed original shape (Fig. $6 a, b$ ). The wall surface now had a slightly granular appearance and bud scars were very conspicuous and numerous. Some cell walls were virtually obliterated by the presence of these features. However, the extracted walls did not show any fibrillar structure. As a control on the techniques used, baker's yeast cell walls were examined after boiling with $2 \%$ hydrochloric acid for $2 \mathrm{~h}$. The procedure produces the fibrillar 'hydroglucan' shown in Fig. 7, as originally described by Houwink \& Kreger (1953).

\section{DISCUSSION}

The observation by Eddy \& Woodhead (1968) that the cell walls of Saccharomyces carlsbergensis contain approximately $20 \%$ of an alkali-soluble glucan has been confirmed for $S$. cerevisiae by our studies. This glucan appears, at first sight, to be distinct from the two other cell-wall glucan components recently described by Manners et al. (1973 a, b, 1974). Hence, it is probable that the yeast cell wall contains at least three separate glucan species. 

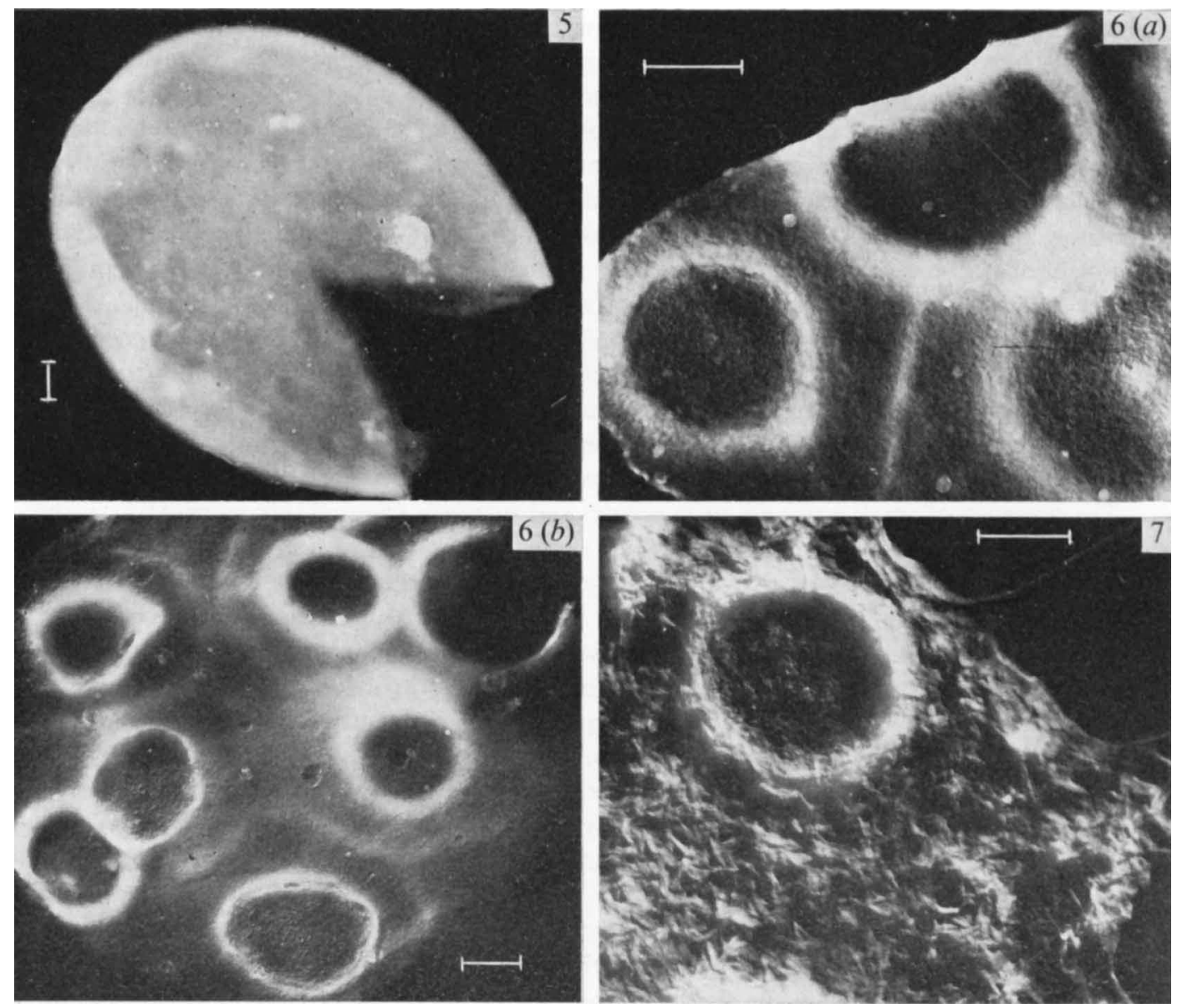

All bar markers represent I $\mu \mathrm{m}$.

Fig. 5. Untreated cell wall of $S$. cerevisiae 1 109.

Fig. 6. Alkali-extracted cell wall (see Fig. I) of (a) S. cerevisiae I 109; (b) baker's yeast.

Fig. 7. Hydroglucan from baker's yeast cell walls (see Results).

It should be emphasized that in this study, the alkali-soluble glucan was obtained from cellwall preparations, whilst in the previous studies, intact yeast cells were used as starting material. Bacon et al. (1969) have shown that glucans are more readily extracted by alkali from isolated cell walls, than from intact cells. The reasons for this difference, which Bacon et al. (1969) have discussed in detail, are not clearly understood. Thus caution is required in comparing and interpreting the results of the extraction with alkali of intact cells and of wall preparations.

Under the culture conditions used, the cell walls of $S$. cerevisiae contained approximately $30 \%$ mannan components $\left(S_{1}, S_{2}\right.$ and a remaining $9 \%$ in wall residue) and $60 \%$ glucan components $\left(\mathrm{G}_{1}, \mathrm{G}_{2}\right.$ and wall residue). In previous studies on the composition of baker's yeast cell walls, values of 30 to $35 \%$ each were reported for the content of the mannan and glucan components (Northcote \& Horne, 1952; Roelofsen, 1953; cf. Bacon et al., 1969). In these cases, cell walls were extracted with hot alkali and consequently incurred the risk 
of degrading the alkali-soluble glucan component (Eddy \& Woodhead, 1968; Bowden \& Hodgson, 1970). It is not surprising, therefore, that low values for the glucan content of the walls were obtained. Mill (I966) has reported values around $45 \%$ for both the glucan and mannan wall components of $S$. cerevisiae and these are possibly more reliable figures since they are based on the determination of glucose and mannose contents in cell-wall hydrolysates rather than in extracted fractions. However, any study of the composition of yeast cell walls is primarily dependent on the quality of the starting cell-wall material. It is now known that yeast cell walls contain associated $(\mathrm{I} \rightarrow 3)-\beta$-D-glucanase activity which, if not checked, causes very substantial wall hydrolysis immediately after cell disruption (Fleet \& Phaff, I974 b). The effect of such activity is to reduce the overall glucan content. The cell walls used in our study were prepared under conditions whereby associated glucanases were inactive and this may explain their much higher glucan content. As demonstrated by McMurrough \& Rose (1967), cell-wall composition is also determined by the environment in which the yeast cells are grown. Environments of glucose abundance, such as used in our studies, are more favourable to a higher glucan content.

The presence of small amounts of mannose and nitrogen (presumably as protein) in the alkali-soluble glucan is not unexpected and suggests that, in the native wall, this glucan fraction may have been part of a much larger polysaccharide-protein complex. Glucanmannan-protein complexes have previously been isolated from baker's yeast cell walls. Kessler \& Nickerson (1959) obtained two such complexes on extracting cell walls with M-potassium hydroxide for $\mathrm{I} \mathrm{h}$ at $30{ }^{\circ} \mathrm{C}$ under nitrogen, whilst Korn \& Northcote (I960) obtained two similar complexes with a milder extraction procedure using ethylenediamine. In both cases, one of the complexes was insoluble at neutral $\mathrm{pH}$ values and it is possible that the glucan moiety of this macromolecule is similar in structure to the glucan described in our study. Although there has been some progress in elucidating the nature of the mannanprotein linkage (Ballou, I974), the nature of any glucan-protein or glucan-mannan linkages is as yet unresolved.

Chemical analysis of the alkali-soluble glucan has shown that it contains mostly $(\mathrm{I} \rightarrow 3)$ $\beta$-D linkages. In this respect and in size (DP about I500), it is very similar to the alkaliinsoluble glucan which forms the rigid component of $S$. cerevisiae cell walls (Manners et al., 1973a). Unlike the latter, however, the alkali-soluble glucan contains a significant percentage ( 8 to I $2 \%$ ) of residues linked solely by C-I and C-6. Both glucans show approximately 3 to $4 \%$ branching involving C-I, C-3 and C-6. The presence of these $\mathrm{I} 50$ or so $(\mathrm{I} \rightarrow 6)$-linked residues seems to be sufficient to alter the solubility properties of the molecule. Consequently, the arrangement of these linkages is important but the exact details cannot be deduced from the available evidence. However, certain facts can be stated. Since gentiotetrose was present in partial acid hydrolysates of the glucan, sequences of at least three $(I \rightarrow 6)$-linked glucose residues must occur. Some of these $(\mathrm{I} \rightarrow 6)$ linkages are dispersed among longer sequences of $(\mathrm{I} \rightarrow 3)$ linkages since the molecule was fragmented to a limited extent by Smith degradation. Since glucosyl-glycerol and, most likely, laminaribiosyl-glycerol were products of Smith degradation, some of the occasional laminaribiosyl and laminaritriosyl units may be flanked on either side by $(I \rightarrow 6)$ linkages. Finally, some of the 3 to $4 \%$ of $(I \rightarrow 6)$ branch points do not connect directly with other $(\mathrm{I} \rightarrow 6)$-linked residues because of the presence of structure (A) (see Results) in the Smith-degraded glucan (Table 2). Further studies are in progress to determine the finer structural details of this new glucan.

Alkali-soluble glucans occur in other yeasts (Phaff, 1971), but in cases where they have been studied, such as in Cryptococcus species (Bacon et al., 1968) and Schizosaccharomyces species (Bush et al., 1974), the molecules have been predominantly $\alpha-(\mathrm{I} \rightarrow 3)$-linked. An 
alkali-soluble glucan similar in composition to the one described in this study was recently found in the hyphal walls of the fungus Pythium acanthicum (Sietsma et al., 1975).

\section{We are indebted to the Science Research Council for financial support for G.H.F.}

\section{REFERENCES}

Aspinall, G. O. \& FerRIER, R. J. (1957). A spectrophotometric method for the determination of periodate consumed during the oxidation of carbohydrates. Chemistry and Industry, I216.

Bacon, J. S. D., Jones, D., Farmer, V. C. \& Webley, D. M. (I968). The occurrence of $\alpha$-(I-3)-glucan in Cryptococcus, Schizosaccharomyces and Polyporus species, and its hydrolysis by a Streptomyces culture filtrate lysing cell walls of Cryptococcus. Biochimica et biophysica acta 158, 313-315.

BaCon, J. S. D., FARMeR, V. C., JoNes, D. \& TAYLOR, I. F. (I969). The glucan components of the cell wall of baker's yeast (Saccharomyces cerevisiae) considered in relation to its ultrastructure. Biochemical Journal II4, 557-567.

BalLou, C. E. (1974). Some aspects of the structure, biosynthesis and genetic control of yeast mannans. In Advances in Enzymology, vol. 40. pp, 239-270. Edited by A. Meister. New York: Wiley.

Bjorndal, H., Hellerqvist, C. G., Lindberg, B. \& Svenson, S. (1970). Gas-liquid chromatography and mass spectrometry in methylation analysis of polysaccharides. Angewandte Chemie (International Edition in English) 9, 610-619.

BowDEN, J. K. \& HodGSON, B. (1970). Evidence against the presence of fibres or chemically distinct layers in the cell wall of Saccharomyces. Antonie van Leeuwenhoek 36, 8I-I08.

Bush, O. A., Horisberger, M., HoRman, I. \& WURSCH, P. (1974). The wall structure of Schizosaccharomyces pombe. Journal of General Microbiology 81, 199-206.

Dubois, M., Gilles, K. A., Hamilton, J. K., Rebers, P. A. \& Smith, F. (1956). Colorimetric method for determination of sugars and related substances. Analytical Chemistry 28, 350-356.

EDDY, A. A. \& WoODHEAD, J. S. (1968). An alkali-soluble glucan fraction from the cell walls of the yeast Saccharomyces carlsbergensis. Federation of European Biochemical Societies Letters I, 67-68.

Elson, L. A. \& Morgan, W. T. J. (1933). A colorimetric method for the determination of glucosamine and chondrosamine. Biochemical Journal 27, 1824-1828.

FLEET, G. H. \& MANNERS, D. J. (1975). Gel chromatography of polysaccharides. Transactions of the Biochemical Society 3, 98I-983.

FLEET, G. H. \& PHAFF, H. J. (1973). Effect of glucanases of yeast and bacterial origin on cell walls of Schizosaccharomyces species. In Yeast, Mould and Plant Protoplasts, pp. 33-59. Edited by J. R. Villanueva, I. Garcia-Acha, S. Gascón and F. Urubaru. London: Academic.

Fleet, G. H. \& PhAFF, H. J. (1974a). Lysis of yeast cell walls: Glucanases from Bacillus circulans WL-I 2. Journal of Bacteriology I19, 207-219.

Fleet, G. H. \& Phaff, H. J. (1974b). Glucanases in Schizosaccharomyces: isolation and properties of the cell wall-associated $\beta$-(I $\rightarrow 3)$-glucanases. Journal of Biological Chemistry 249, 1717-I 728.

Fleming, M., HIRst, E. \& ManNers, D. J. (I966). The constitution of laminarin. Part VI. The fine structure of soluble laminarins. In Proceedings of the Fifth International Seaweed Symposium, pp. 255-260. Oxford and New York: Pergamon.

Goldstein, I. J., HaY, G. W., Lewis, B. A. \& SMith, F. (1965). Controlled degradation of polysaccharides by periodate oxidation, reduction and hydrolysis. In Methods in Carbohydrate Chemistry, vol. V. pp. 36i-370. Edited by R. L. Whistler. New York and London: Academic.

GuNJA-SMITH, Z. \& SMITH, E. (1974). Evidence for the periplasmic location of glycogen in Saccharomyces. Biochemical and Biophysical Research Communications 56, 588-592.

Hellerqvist, C. G., LindBerg, B. \& Samuelsson, K. (1968). Methylation analysis of pustulan. Acta chemica scandanavica 22, 2736-2737.

HoffmanN, G. C., Simson, B. N. \& Timell, R. E. (1971). Structure and molecular size of pachyman. Carbohydrate Research 20, $185-188$.

HouwINk, A. L. \& KREGER, D. R. (1953). Observations on the cell wall of yeast. Antonie van Leeuwenhoek I9, I-24.

HuggetT, A. ST. G. \& Nixon, D. A. (1957). Enzymic determination of blood glucose. Biochemical Journal 66, $12 \mathrm{P}$.

Jones, D., Gordon, A. H. \& BACon, J. S. D. (1974). Co-operative action by endo- and exo- $\beta$-(I $\rightarrow 3$ )-glucanases from parasitic fungi in the degradation of cell wall glucans of Sclerotinia sclerotium (Lib) de Bary. Biochemical Journal n40, 47-55.

KessLeR, G. \& NICKERSON, W. J. (1959). Glucomannan-protein complexes from cell walls of yeasts. Journal of Biological Chemistry 234, 2281-2283. 